\title{
Evaluation of Concentrate Supplementations of Grazing Kalahari Red Does on Udder and Teat Morphometry from Pregnancy till Kidding
}

\author{
Oderinwale $\mathrm{OA}^{1 *}$, Oluwatosin $\mathrm{BO}^{1,2}$, Amosu $\mathrm{SD}^{3}$, Sanusi $\mathrm{GO}^{3}$, Adeyemo $\mathrm{AJ}^{3}$, Shuaibu $\mathrm{AY}^{1}$, Olaniyi $\mathrm{MB}^{1}$, Jolaosho \\ $00^{3}$ and Madou Camara ${ }^{1}$ \\ ${ }^{1}$ Livestock Science and Sustainable Environment Programme, World Bank Africa Centre of Excellence in Agricultural Development and Sustainable \\ Environment (CEADESE), Federal University of Agriculture Abeokuta, PMB 2240, Abeokuta, Ogun State, Nigeria
}

${ }^{2}$ Institute of Food Security, Environmental Resources and Agricultural Research (IFSERAR), Federal University of Agriculture Abeokuta, PMB 2240, Abeokuta, Ogun State, Nigeria

${ }^{3}$ Department of Animal Production and Health, Federal University of Agriculture, Abeokuta, PMB 2240, Abeokuta, Ogun State, Nigeria

Submission: March 07, 2019; Published: March 26, 2019

*Corresponding author: Oderinwale OA, Livestock Science and Sustainable Environment Programme, World Bank Africa Centre of Excellence in Agricultural Development and Sustainable Environment (CEADESE), Federal University of Agriculture, Abeokuta, PMB 2240, Abeokuta, Ogun State, Nigeria, Tel: 2347039432202/ 2348054468382; Email: oderinwale.olatunde@gmail.com

\begin{abstract}
A study was conducted to investigate effects of concentrate diets supplementation at three different protein levels of Kalahari Red does grazed on Rhodes grass (Chloris gayana) on their udder and teat morphometry from 9th week of pregnancy till kidding in South-Western Nigeria. Thirty-three matured primiparous Kalahari Red does with age range of 2 to $21 / 2$ years whose average body weight was $38.10 \pm 1.13 \mathrm{~kg}$ were randomly allotted to 3 treatment groups of 11 does per treatment. Dietary concentrate diets with crude protein levels of $12.42 \%$ (LPD i.e. 124.93gday-1), $14.18 \%$ (MPD i.e. 145.87gday-1) and 16.35\% (HPD i.e. 168.19gday-1) were fed to the does at 3\% of their body weight after mating till kidding. Data on udder measurements such as Udder Length, Udder Circumference, Udder Width, Udder Volume, Distance between Teats, Teat Height from Ground, Teat Length, Teat Width and Teat Circumference were taken on the does starting from 9th to 22nd weeks of pregnancy using graduated flexible canvas tape. It was observed at the end of the study that Kalahari Red does fed MPD had better increment in size (from weeks 9 to 22$)$ for all udder measurements such as udder length $(10.21 \mathrm{~cm})$, udder width $(8.79 \mathrm{~cm})$, udder circumference $(28.76 \mathrm{~cm})$, and udder volume $(2440.46 \mathrm{~cm} 3)$ compared to other dietary treatments. In conclusion, dietary supplementation of grazing pregnant Kalahari Red does with concentrate diet containing $14.18 \% \mathrm{CP}$ improved best the udder parameters.
\end{abstract}

Keywords: Kalahari Red goat; Udder; Grazing; Pregnancy; Concentrate supplementation

Abbrevations: DNA: Deoxyribonucleic Acid; UL: Udder Length; UC: Udder Circumference; UV: Udder Volume; THG: Teats Height from Ground; DBT: Distance between Teats; TL: Teat Length; TW: Teat Width; TC: Teat Circumference

\section{Introduction}

Udder growth is a complex process, which is characterized by mammary cell hyperplasia during gestation and early lactation; cell hypertrophy during late lactation and cell death during declining lactation [1]. Udder growth, which results from increase in udder dimensions in goats, has been described by several indices [2]. Most researchers adjudged deoxyribonucleic acid (DNA) to be the best parameter for assessing udder growth, though other measurements including untrimmed and trimmed wet weights of udder, dried fat-free tissue weights, ribonucleic acid contents by Anderson [3] and udder dimensions by James \& Osinowo [4] have been determined. Early studies on the pattern of udder growth in goats relied greatly on empirical approach involving multiple comparisons of means rather than using regression models that contain linear, quadratic, cubic, exponential and logarithm terms [5].
Some Kalahari Red goats were imported to Federal University of Agriculture Abeokuta, Ogun State, Nigeria from South Africa. Since there is little or no record on udder and teat growth and measurement of the goats, there is need to embark on this study to know response of the goats to various concentrate diets supplementation and to recommend which protein level is the optimum for udder and teat growth and development in Nigeria.

\section{Materials and Methods}

\section{Experimental Location}

The study was conducted at Kalahari Red goat Unit of Livestock Production Research Programme under Institute of Food Security, Environmental Resources and Agricultural Research (IFSERAR), Federal University of Agriculture, Abeokuta, Ogun 
State, Nigeria. The region is $76 \mathrm{~m}$ above sea level and falls within latitudes 7o18'2" N and 7o18'30" N; and longitude 3o22'10" E and $3022^{\prime} 41^{\prime \prime}$ E. The climate is humid and located in the forest zone of South-Western Nigeria. The mean annual precipitation and the temperature are $1,330 \mathrm{~mm}$ and $29.3^{\circ} \mathrm{C}$ respectively. It has average relative humidity of $80 \%$ throughout the year.

\section{Animal Management and Experimental Procedure}

The study which lasted for a period of 13 weeks was conducted by using 33 matured primiparous Kalahari Red does within age range of 2-21/2 years with an average body weight of $38.10 \pm 1.13 \mathrm{~kg}$. Flock treatment was carried out by the veterinarians on the farm two weeks before mating in order to ensure that only goats that are in good health conditions were used. Oxytetracycline $20 \%$ LA (Oxytetracycline $200 \mathrm{mg} / \mathrm{ml}$ as dihydrate) was administered intramuscularly at $1 \mathrm{ml}$ per $20 \mathrm{~kg}$ bodyweight, while Vita-Strong ${ }^{\circledR}$ Injection was administered intramuscularly at $1 \mathrm{ml}$ per $10 \mathrm{~kg}$ bodyweight as vitamin supplement and anti-stress. Ivanor ${ }^{\circledR}$ (Ivermectin Injection $10 \mathrm{mg} / \mathrm{ml}$ ) was also administered subcutaneously at $1 \mathrm{ml}$ per $50 \mathrm{~kg}$ bodyweight to control gastro-intestinal worms, fly larvae, lice, ticks and mites. Experimental animals were selected from flock of 68 does. Three healthy, experienced and vigorous Kalahari Red bucks were used to detect goats on heat. The bucks used are 21/2 years old with an average weight of $44.70 \mathrm{~kg}$.
Goats detected to be on heat were placed in a holding pen as experimental animals. The selected goats were ear-tagged and randomly assigned to pen houses used for the study. Mating was done by introduction of the 3 Kalahari Red bucks into the pen houses (i.e. a buck/treatment). Proper observation was done to ensure that conception takes place before data collection commenced. The goats, after mating were fed experimental concentrate diets at three levels of protein.

\section{Feeding of the does}

The does were fed 3 experimental concentrate diets (Table 1) at $3 \%$ of their body weight on dry matter basis as follows: Low (LPD, 12.42\% CP), Medium (MPD, 14.18\% CP) and High (HPD, $16.35 \% \mathrm{CP}$ ) protein diets as supplements to forage (Chloris gayana) on the paddock. These dietary supplementations resulted into each doe receiving crude protein of $124.93 \mathrm{~g} /$ day, $145.87 \mathrm{~g} /$ day, and $168.19 \mathrm{~g} /$ day from the consumption of low, medium and high protein diets respectively. There were 11 does per treatment. Feeding of the experimental diets is done twice a day i.e. half portion in the morning by 8:00h and the remaining portion in the evening by $16: 30 \mathrm{~h}$. Grazing of the does was done by $10: 00 \mathrm{~h}$ after morning feeding and the does were returned from grazing by 16:00h. Fresh and clean portable water was made available to the does daily ad libitum throughout the study.

Table 1: Gross compositions (\%) of experimental diets fed to Kalahari Red does in Nigeria.

\begin{tabular}{|c|c|c|c|}
\hline & \multicolumn{3}{|c|}{ Experimental concentrate diets } \\
\hline Ingredients & Low Protein & Medium Protein & High Protein \\
\hline Maize & 10 & 10 & 10 \\
\hline Unpeeled Cassava Root Meal & 50 & 19.5 & 50 \\
\hline Wheat Offal & 10 & 30 & 28 \\
\hline Palm Kernel Cake & 24 & 34.5 & 6.5 \\
\hline Groundnut Cake & 1.5 & 3 & 3 \\
\hline Bone Meal & 3 & 1.5 & 1 \\
\hline Salt & 1 & 0.5 & 0.5 \\
\hline Tremix & 0.5 & 100 & 100 \\
\hline
\end{tabular}

*contains Vitamin A (I.U.) 10,000.000; Vitamin D (I.U.) 2,000,000; Vitamin E (I.U) 20,000; Vitamin K (mg) 2,250; Riboflavin (mg) 5000; Pyridoxine (mg) 275; Biotin (mg) 50; Pantothenic acid (mg) 7500; Vitamin $B_{1}$ (mg) 175; Vitamin $B_{12}$ (mg) 15.0; Niacin (mg) 27,500; Folic acid (mg) 7500. Choline Chloride (mg) 400; Antioxidant (mg) 125; Fe (g) 20.0; Zn (g) 50.0; Mn (g) 80.0; Cu (g) 5.0g; I (g) 12.0; Co (mg) 200; Se (mg) 200.

\section{Udder and Teat Measurements}

Data on udder and teat measurements were taken on the pregnant does at 2 weeks interval starting from week 9 after successful mating till all the does kidded. Restraining of the does was done by letting the does into a milking crate, hold the head by another person, then tie the hind legs to the walls of the milking crate. The udder and teat parameters were not taken at initial weeks before week 9 because they were not well developed and distended before this time.

All measurements as indicated on Figure 1 were taken using flexible canvas tape graduated in centimetre $(\mathrm{cm})$.

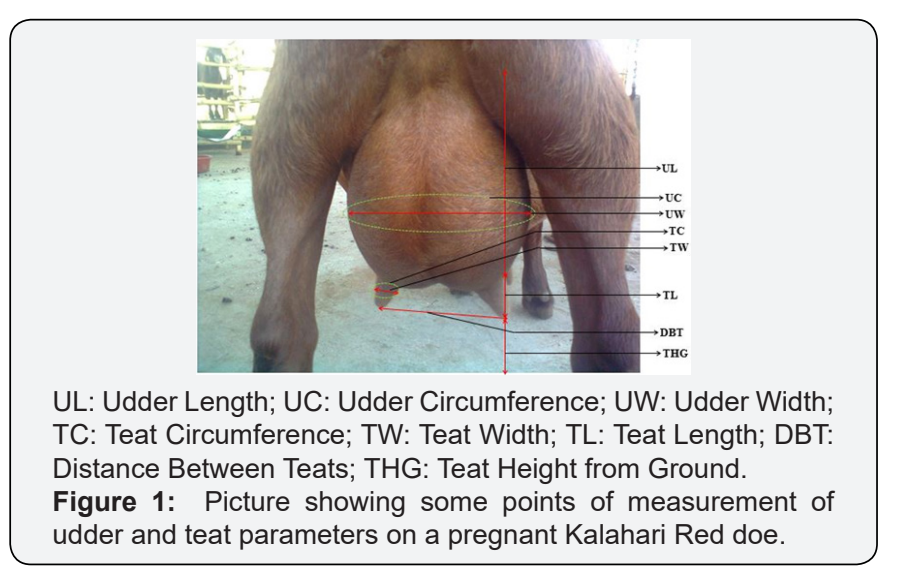


Udder and teat measurements taken on the does included the following:

a. Udder Length (UL): This was taken between cranial and caudal attachment of udder with body of the doe i.e. measurement between the point of attachment of udders to body of the does and base of the teats. This measurement was taken on both sides of the does (i.e. left and right), then divided by 2;

b. Udder Width (UW): This was taken between two lateral lines of attachment of the udders with abdominal wall of the does from the rear;

c. Udder Circumference (UC): This was taken as the perimeter i.e. horizontal distance round the udders of the does at the widest part of the udders. This was because of the different shapes and sizes of the udder during pregnancy;

d. Udder Volume (UV): The UV was not measured directly on the does [6].

UV values were determined using formula below:

Where: $=22 / 7$

$$
\begin{gathered}
U V=\frac{4}{3} \Pi \mathbf{r}^{3}\left(\mathrm{~cm}^{3}\right) \\
r=\frac{(U L+U W)}{4(\mathrm{~cm})}
\end{gathered}
$$

UL is the Udder Length $(\mathrm{cm})$

UW is the Udder Width $(\mathrm{cm})$

e. Distance between Teats (DBT): This was taken as measurement between the tips of two most prominent teats ( 1 from each half of the udder) of the does when they were in resting states.

f. Teats Height from Ground (THG): This was taken as distance between the tips of two most prominent teats ( 1 from each half of the udder) of the does (taken separately) from the ground while the does were standing still on a levelled ground. The values obtained were later added together, and then divided by 2 .

g. Teat Length (TL): This was taken as the measurement from basal part of the udder length to the tip of the teats i.e. measurement from point of attachment of teats (to the udder) to tips of the teats.

h. Teat Width (TW): This was taken as diameters of the two most prominent teats without flattening of the teats. The tape was placed across the teat horizontally to take its diameter without applying pressure on it. The values obtained from teats on both halves were added together, then divided by 2 .

i. Teat Circumference (TC): This was taken as the perimeter i.e. horizontal distance round the two most prominent teats of the does. The values obtained from both teams were summed up and then divided by 2 .
Aliquots were taken from experimental concentrate diets and Rhodes grass to determine nutrient composition of the samples. The samples were oven-dried at $65{ }^{\circ} \mathrm{C}$ for 3 days until constant weight was obtained, then milled with industrial blender into fine particles. The blended samples were kept until when needed for laboratory analysis. The nutrient composition was determined by following the procedure of A.O.A.C. (2005) at the Food Processing Laboratory in Department of Food Science and Technology, Federal University of Agriculture Abeokuta, Nigeria. The nutrient composition of the concentrate diets fed, and Rhodes grass grazed upon by the pregnant Kalahari Red goats is presented in Table 2.

Table 2: Nutrient composition of experimental concentrate diets and

\begin{tabular}{|c|c|c|c|c|}
\hline \multirow[b]{2}{*}{ Parameters (\%) } & \multicolumn{3}{|c|}{$\begin{array}{c}\text { Experimental concentrate } \\
\text { diets }\end{array}$} & \multirow[b]{2}{*}{$\begin{array}{c}\text { Rhodes } \\
\text { grass }\end{array}$} \\
\hline & LPD & MPD & HPD & \\
\hline Dry Matter & 88 & 90 & 90 & 39 \\
\hline Crude Protein & 12.42 & 14.18 & 16.35 & 3.24 \\
\hline Ether Extract & 7.49 & 4.5 & 8.44 & 0.15 \\
\hline Ash & 7.38 & 6.03 & 8.19 & 3.33 \\
\hline Nitrogen Free Extract & 57.23 & 63.29 & 53.38 & 29.39 \\
\hline Organic Matter & 92.62 & 93.97 & 91.81 & 96.67 \\
\hline Neutral Detergent Fibre & 54.67 & 55.72 & 57.22 & 58.92 \\
\hline Acid Detergent Fibre & 42.46 & 40.32 & 41.73 & 46.72 \\
\hline Acid Detergent Lignin & 23.36 & 25.96 & 25.63 & 24.82 \\
\hline Hemicellulose & 12.21 & 15.4 & 15.49 & 12.2 \\
\hline Cellulose & 19.1 & 14.36 & 16.1 & 21.9 \\
\hline${ }^{*} \mathrm{ME}(\mathrm{MJ} / \mathrm{kg} \mathrm{DM})$ & 14.95 & 15.64 & 15.6 & 14.56 \\
\hline
\end{tabular}
Rhodes grass (Chloris gayana) fed to pregnant Kalahari Red goats.

Calculated using MAFF (1984) equation

LPD: Low Protein Diet; MPD: Medium Protein Diet; HPD: High Protein Diet; ME: Metabolizable Energy

\section{Results and Discussion}

Udder and teat morphometry from $9^{\text {th }}$ week of pregnancy until kidding of pregnant Kalahari Red does grazing on Rhodes grass (Chloris gayana) supplemented with three concentrate diets is presented in Tables 3 \& 4. Supplementation of grazed pregnant Kalahari Red does with MPD resulted into does with superior udder and teat development taken with the exception of teat length where HPD supplemented does recorded highest value. HPD and LPD supplemented does recorded lowest values for all udder and teat measurements taken respectively. This could be attributed to improved protein utilisation by the does which resulted in improved maternal body tissues growth, thus enhanced udder and teat development. Mean udder length (UL) ranged from 6.98$15.74 \mathrm{~cm}$ with mean increment rate of $0.73 \mathrm{cmwk}-1$, where does 
fed MPD had greatest influence on UL with an increment rate of $0.85 \mathrm{cmwk}-1$. It was observed that major increment in UL was observable in 3rd trimester (Figure 2). This result agreed with James \& Osinowo [4] who reported that there is exponential increase in udder dimensions during the last trimester of pregnancy than ear- ly trimester of pregnancy. The graph (Figure 2) obtained from UL development was non-linear, which was corroborated by James [7] who reported that the pattern of udder growth during pregnancy is non-linear.

Table 3: Udder morphometry from 9th week of pregnancy until kidding of pregnant Kalahari Red does grazing on Rhodes grass (Chloris gayana) supplemented with three concentrate diets.

\begin{tabular}{|c|c|c|c|c|c|c|c|c|c|}
\hline \multicolumn{8}{|c|}{ Weeks of Pregnancy } & \multirow[b]{2}{*}{ Increment (cm) } & \multirow[b]{2}{*}{$\begin{array}{c}\text { Increment Rate } \\
\text { (cm/week) }\end{array}$} \\
\hline Parameters & 9 & 11 & 13 & 15 & 17 & 19 & KD & & \\
\hline \multicolumn{10}{|c|}{ UL (cm) } \\
\hline LPD & 6.02 & 6.32 & 7.62 & 8.92 & 10.67 & 13.5 & 15.6 & 9.58 & 0.8 \\
\hline MPD & 7.79 & 8.57 & 10.73 & 13.01 & 15 & 17 & 18 & 10.21 & 0.85 \\
\hline HPD & 7.12 & 7.26 & 8.1 & 8.94 & 10.72 & 12.94 & 13.63 & 6.51 & 0.54 \\
\hline Mean & 6.98 & 7.38 & 8.82 & 10.29 & 12.13 & 14.48 & 15.74 & 8.77 & 0.73 \\
\hline \multicolumn{10}{|c|}{$\mathrm{UW}(\mathrm{cm})$} \\
\hline LPD & 5.58 & 5.72 & 6.25 & 7.08 & 9.5 & 11 & 12.5 & 6.92 & 0.58 \\
\hline MPD & 7.71 & 8.4 & 10.14 & 11.86 & 13.29 & 14 & 16.5 & 8.79 & 0.73 \\
\hline HPD & 6.94 & 7.2 & 7.68 & 8.42 & 10 & 11.4 & 13.13 & 6.19 & 0.52 \\
\hline Mean & 6.74 & 7.11 & 8.02 & 9.12 & 10.93 & 12.13 & 14.04 & 7.3 & 0.61 \\
\hline \multicolumn{10}{|l|}{$\mathrm{UC}(\mathrm{cm})$} \\
\hline LPD & 17.68 & 19.3 & 21.92 & 26.53 & 30.75 & 36.65 & 38.33 & 20.65 & 1.72 \\
\hline MPD & 22.44 & 23.83 & 27.36 & 34.87 & 38.41 & 47.55 & 51.2 & 28.76 & 2.4 \\
\hline HPD & 22.02 & 23.26 & 24.5 & 24.74 & 29.08 & 35.38 & 38.53 & 16.51 & 1.38 \\
\hline Mean & 20.71 & 22.13 & 24.59 & 28.71 & 32.75 & 39.86 & 42.68 & 21.97 & 1.83 \\
\hline \multicolumn{10}{|c|}{$\mathrm{UV}\left(\mathrm{cm}^{3}\right)$} \\
\hline LPD & 102.2 & 114.09 & 197.88 & 282.59 & 556.89 & 986.89 & 1476.6 & 1374.4 & 114.53 \\
\hline MPD & 247.93 & 325.15 & 607.09 & 1037.4 & 1522.06 & 1950.38 & 2688.38 & 2440.46 & 203.37 \\
\hline HPD & 181.99 & 197.96 & 276.89 & 365.99 & 596.41 & 968.11 & 1256.14 & 1074.15 & 89.51 \\
\hline Mean & 177.37 & 212.4 & 360.62 & 561.99 & 891.79 & 1301.79 & 1807.04 & 1629.67 & 135.81 \\
\hline
\end{tabular}

$\mathrm{cm}^{3} /$ week (for udder volume)

UL: Udder Length; UW: Udder Width; UC: Udder Circumference; UV: Udder Volume; KD: within 24hours before Kidding; LPD: Low Protein Diet; MPD: Medium Protein Diet; HPD: High Protein Diet 
Table 4: Teat morphometry from 9th week of pregnancy until kidding of pregnant Kalahari Red does grazing on Rhodes grass (Chloris gayana) supplemented with three concentrate diets.

\begin{tabular}{|c|c|c|c|c|c|c|c|c|c|}
\hline \multirow[b]{2}{*}{ Parameters } & \multicolumn{7}{|c|}{ Weeks of Pregnancy } & \multirow[b]{2}{*}{ Increment (cm) } & \multirow[b]{2}{*}{ Increment Rate (cm/week) } \\
\hline & 9 & 11 & 13 & 15 & 17 & 19 & KD & & \\
\hline \multicolumn{10}{|c|}{ DBT (cm) } \\
\hline LPD & 5.98 & 6.02 & 6.55 & 8.33 & 10.65 & 11.92 & 13.03 & 7.05 & 0.59 \\
\hline MPD & 7.44 & 8.74 & 10.14 & 12 & 12.9 & 13.5 & 19 & 11.56 & 0.96 \\
\hline HPD & 6.06 & 7.08 & 8.1 & 9.12 & 10.06 & 11.12 & 12.28 & 6.22 & 0.52 \\
\hline Mean & 6.49 & 7.28 & 8.26 & 9.82 & 11.2 & 12.18 & 14.77 & 8.27 & 0.69 \\
\hline \multicolumn{10}{|c|}{ THG (cm) } \\
\hline LPD & 31.75 & 31.33 & 29.92 & 28.5 & 25.45 & 24.63 & 24.1 & $-7.65^{\#}$ & $-0.64^{*}$ \\
\hline MPD & 31.61 & 30.43 & 27.1 & 26.81 & 25.7 & 23.15 & 23 & $-8.61^{\#}$ & $-0.72^{*}$ \\
\hline HPD & 33.48 & 32.64 & 30.8 & 28.96 & 27.62 & 26.14 & 25.48 & $-8.01^{\#}$ & $-0.67^{*}$ \\
\hline Mean & 32.28 & 31.47 & 29.27 & 28.09 & 26.26 & 24.64 & 24.19 & $-8.09^{\#}$ & $-0.67^{*}$ \\
\hline \multicolumn{10}{|c|}{ TL (cm) } \\
\hline LPD & 2.75 & 2.9 & 3.05 & 3.2 & 3.2 & 3.22 & 3.58 & 0.83 & 0.07 \\
\hline MPD & 2.93 & 3 & 2.94 & 3.1 & 3.34 & 3.6 & 4.1 & 1.17 & 0.1 \\
\hline HPD & 2.38 & 2.62 & 2.86 & 3.1 & 3.28 & 3.42 & 3.58 & 1.2 & 0.1 \\
\hline Mean & 2.69 & 2.84 & 2.95 & 3.13 & 3.27 & 3.41 & 3.75 & 1.06 & 0.09 \\
\hline \multicolumn{10}{|c|}{ TW (cm) } \\
\hline LPD & 1.55 & 1.6 & 1.65 & 1.7 & 1.82 & 1.92 & 2.15 & 0.6 & 0.05 \\
\hline MPD & 1.51 & 1.66 & 1.9 & 1.9 & 2.11 & 2.25 & 3.1 & 1.59 & 0.13 \\
\hline HPD & 1.38 & 1.52 & 1.66 & 1.8 & 1.84 & 2.08 & 2.3 & 0.92 & 0.08 \\
\hline Mean & 1.48 & 1.59 & 1.74 & 1.8 & 1.92 & 2.08 & 2.52 & 1.04 & 0.09 \\
\hline \multicolumn{10}{|c|}{$\mathrm{TC}(\mathrm{cm})$} \\
\hline LPD & 4.55 & 4.57 & 4.58 & 4.6 & 4.8 & 5.4 & 5.08 & 0.52 & 0.04 \\
\hline MPD & 4.31 & 4.46 & 4.49 & 5.07 & 5.06 & 6.45 & 6.9 & 2.59 & 0.22 \\
\hline HPD & 3.58 & 4.04 & 4.5 & 4.96 & 4.26 & 5.32 & 5.38 & 1.8 & 0.15 \\
\hline Mean & 4.15 & 4.35 & 4.52 & 4.88 & 4.71 & 5.72 & 5.78 & 1.64 & 0.14 \\
\hline
\end{tabular}

\# Decrement ; *Decrement rate

DBT: Distance Between Teats; THG: Teat Height from Ground; TL: Teat Length; TW: Teat Width; TC: Teat Circumference; KD: within 24hours before Kidding; LPD: Low Protein Diet; MPD: Medium Protein Diet; HPD: High Protein Diet

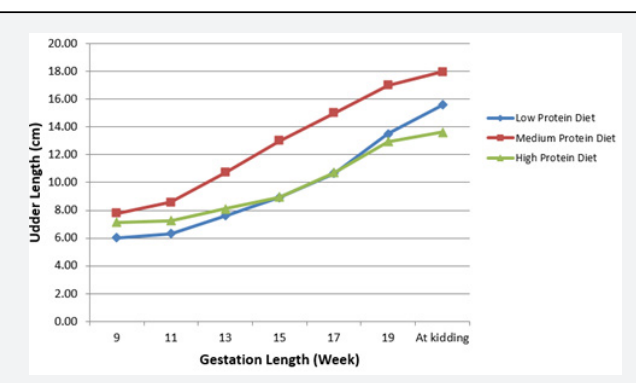

Figure 2: Udder length changes from 9th week to kidding of pregnant Kalahari Red does grazing on Rhodes grass (Chloris gayana) supplemented with three concentrate diets.

Mean udder width range of $6.74-14.04 \mathrm{~cm}$ was obtained, while mean range of $20.71-42.68 \mathrm{~cm}$ with mean increment rate of $1.83 \mathrm{cmwk}-1$ was obtained for udder circumference (UC). Does fed MPD recorded most increased UC with $28.76 \mathrm{~cm}$ as increment. This implied that MPD had tendency of producing does with most devel- oped UC. Graph obtained (Figure 3) from UC was a non-linear and sloped from right to left downwards. James et al. (2008) obtained similar graphs of UC for West African Dwarf, Sahel and Red Sokoto goats. Udder volume (UV) had mean range of $177.37-1807.04 \mathrm{~cm}^{3}$, with mean increment rate of $135.81 \mathrm{~cm}^{3} \mathrm{wk}-1$. Does under MPD recorded highest increment value $\left(2440.46 \mathrm{~cm}^{3}\right)$. There was noticeable and appreciable increment in UV of the does starting from week 15 of pregnancy. This result was in line with Hurley (2006) who reported that the rate of mammary growth during peri-partum was higher than the rate during early and mid-pregnancy. The rate of this growth was attributable to extensive lobulo-alveolar development leading to rapid increase in the size of udder [8-10]. Graph obtained (Figure 4) from UV was a non-linear and sloped from left to right upwards. It was observed that there is an inverse relationship between teat height from ground (THG) and UL. An increase in UL leads to decrease in THG and vice versa. Mean THG 
ranged from 32.28-24.16cm with decrement rate of $-0.67 \mathrm{cmwk}-1$. The graph (Figure 5) of THG was a non-linear graph that sloped from left to right downwards.

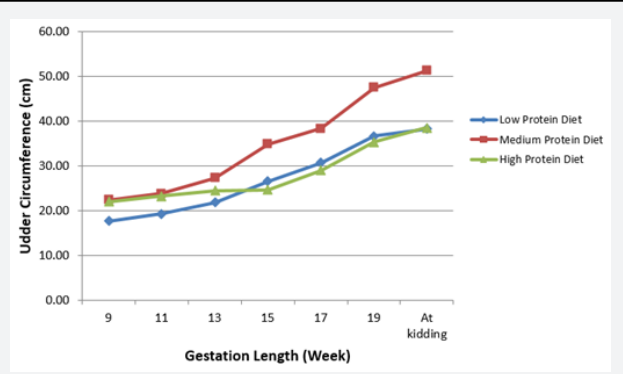

Figure 3: Udder circumference changes from 9th week to kidding of pregnant Kalahari Red does grazing on Rhodes grass (Chloris gayana) supplemented with three concentrate diets.

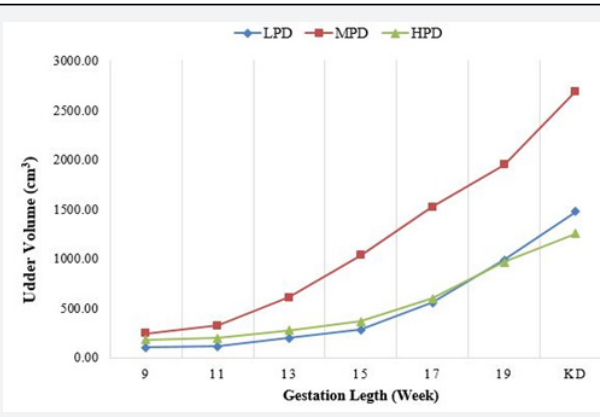

KD: within 24hours before Kidding; LPD: Low Protein Diet; MPD: Medium Protein Diet; HPD: High Protein Diet

Figure 4: Udder volume changes from 9th week to kidding of pregnant Kalahari Red does grazing on Rhodes grass (Chloris gayana) supplemented with three concentrate diets.

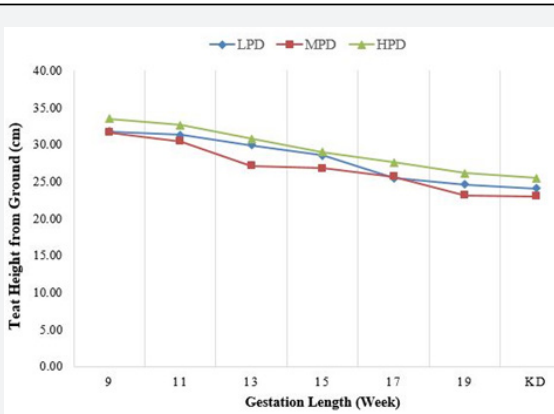

KD: within 24hours before Kidding; LPD: Low Protein Diet; MPD: Medium Protein Diet; HPD: High Protein Diet

Figure 5: Teat height from ground changes from 9th week to kidding of pregnant Kalahari Red does grazing on Rhodes grass (Chloris gayana) supplemented with three concentrate diets.

\section{Conclusion}

Supplementation of pregnant Kalahari Red does graze on Rhodes grass with medium protein $(14.18 \% \mathrm{CP})$ diet recorded most superior increments in udder and teat measurements such as udder length, udder width, udder circumference, udder volume, distance between teats, teat width, and teat circumference.

\section{Acknowledgement}

The authors are grateful to Tertiary Education Trust Fund (TETFund) for funding the research, the fund was facilitated by Directorate of Grants Managements (DGM), and IFSERAR, FUNAAB. Also, to IFSERAR, for providing the Kalahari Red goats with all necessary materials on the farm.

\section{Conflict of Interest Statement}

The authors declare that they have no conflict of interest.

\section{Statement of Animal Rights}

All applicable International, National, and Institutional guidelines for the care and use of animals were followed in the conduct of this research.

\section{Informed Consent}

Informed consent was obtained from all individual participants included in this study.

\section{References}

1. Knight CH, Wilde CJ (1993) Mammary cell changes during pregnancy and lactation. Livestock Production Science 35: 3-19.

2. Anderson RR (1974) Endocrinal control. Page 97 in lactation: A comprehensive treatise. Larson B, Smith V (Eds.), Academic Press Inc., New York, USA.

3. Anderson RR, Harness JR, Snead AF, Salah MS (1981) Mammary growth pattern in goats during pregnancy and lactation. Journal of Dairy Science 64: 427-432.

4. James IJ, Osinowo OA (2004) Changes in udder size and liveweight of West African Dwarf, Red Sokoto and Sahel goats during lactation and their phenotypic relationship with partial daily milk yield. Nigerian Journal of Animal Production 31(1): 119-129.

5. Anderson RR, Wahab IM (1990) Changes in parenchyma and stroma of goat udders during pregnancy, lactation and involution. Small Ruminant Research 3: 605-615.

6. Amao OA (1999) Evaluation of udder traits in West Africa Dwarf and Red Sokoto goats. M. Agric. Thesis Department of Animal Production and Health, University of Agriculture, Abeokuta, Nigeria.

7. James IJ, Osinowo OA, Ozoje MO, Fanimo OA (2008) Modelling the pattern of udder growth during pregnancy and lactation in three Nigerian goat breeds. ASSET Series A 8(2): 169-179.

8. Hurley WL (2006) Mammary gland development during pregnancy. In: Mammary Development Resources.

9. Duncan DB (1955) Multiple range and Multiple F-tests. Biometrics 11: $1-42$.

10. SAS (2002) User's Guide. Statistical Analysis Institute Inc. Cary, N.C. 


\section{Your next submission with Juniper Publishers} will reach you the below assets

- Quality Editorial service

- Swift Peer Review

- Reprints availability

- E-prints Service

- Manuscript Podcast for convenient understanding

- Global attainment for your research

- Manuscript accessibility in different formats ( Pdf, E-pub, Full Text, Audio)

- Unceasing customer service

Track the below URL for one-step submission https://juniperpublishers.com/online-submission.php 